\title{
Methyl 3-Methyl-2H-azirine-2-carboxylate Photochemistry Studied by Matrix-isolation FTIR and DFT Calculations
}

\author{
Agnieszka Kaczor, ${ }^{\dagger, \S}$ Andrea Gómez-Zavaglia, ${ }^{\dagger, \dagger}$ Ana L. Cardoso, ${ }^{\dagger}$ \\ Teresa M. V. D. Pinho e Melo, ${ }^{\dagger}$ and Rui Fausto*, $\dagger$ \\ Department of Chemistry, University of Coimbra, P-3004-535 Coimbra, Portugal, Faculdad de Farmacia y \\ Bioquímica, Universidad de Buenos Aires, Junín 956, 1113 Buenos Aires, Argentina, and Faculty of Chemistry, \\ Jagiellonian University, Ingardena 3, 30-060 Krakow, Poland
}

Received: June 28, 2006; In Final Form: July 26, 2006

\begin{abstract}
The aliphatic $2 \mathrm{H}$-azirine, methyl 3-methyl-2H-azirine-2-carboxylate (MMAC), has been synthesized and its monomeric form investigated by IR spectroscopy in an argon matrix, at $10 \mathrm{~K}$, as well as theoretically (DFT/ B3LYP/6-311++G(d,p)). Two low-energy conformers of MMAC $(\mathrm{Ct}$ and $\mathrm{Cc})$ were found in the matrix, both exhibiting the cis conformation around the $\mathrm{C}-\mathrm{O}$ bond but differing in the arrangement around the $\mathrm{C}-\mathrm{C}_{\alpha}$ bond. The two conformers were photoreactive upon in situ broadband UV excitation $(\lambda>235 \mathrm{~nm})$, yielding nitrile ylide $(\mathrm{P} 1)$ and ketene imine $(\mathrm{P} 2)$ type products, which resulted from cleavage of the $\mathrm{C}-\mathrm{C}$ or $\mathrm{C}-\mathrm{N}$ bond, respectively. The kinetics of the reactions leading to the formation of P1 and P2 are of first order, with the processes being favored when the reactant is in the $\mathrm{Cc}$ conformation. Very interestingly, the $\mathrm{C}-\mathrm{N}$ bond photocleavage, which is unusual for aliphatic $2 \mathrm{H}$-azirines, was found to be preferred over the generally favored in $2 \mathrm{H}$-azirines $\mathrm{C}-\mathrm{C}$ bond breakage. This behavior is attributed to the presence in the molecule of the electronwithdrawing methoxycarbonyl substituent, which accelerates the intersystem crossing toward the $\mathrm{T}_{1}$ triplet state and, in this way, favors the $\mathrm{C}-\mathrm{N}$ bond cleavage. In addition to the primary photoprocesses leading to formation of P1 and P2, secondary photoprocesses leading to the decarboxylation and decarbonylation of P2 have been also observed.
\end{abstract}

\section{Introduction}

$2 \mathrm{H}$-Azirines are compounds with a three-membered unsaturated ring containing one nitrogen atom. The strain energy of the ring was estimated as ca. $45-47 \mathrm{~kJ} \mathrm{~mol}^{-1}$ (44.6 and 46.7 $\mathrm{kJ} \mathrm{mol}^{-1}$ at the MP2/6-31G(d) and B3LYP/6-31G(d) levels of approximation, respectively) for the smallest member of the family-unsubstituted $2 \mathrm{H}$-azirine. ${ }^{1}$ The intrinsic strain of the three-membered ring system results in high reactivity of $2 \mathrm{H}$ azirines, from which a variety of products can be obtained via thermal- ${ }^{2-5}$ or photoexcitation ${ }^{3,5-7}$ or by reaction of $2 \mathrm{H}$-azirines with nucleophiles ${ }^{8,9}$ or electrophiles. ${ }^{1}$ Therefore, $2 H$-azirines have been extensively studied as reagents in organic synthesis, and they are nowadays recognized as important intermediates in the preparation of acyclic and cyclic nitrogen-containing compounds. ${ }^{6,10-17}$

The thermal and photochemical excitation of $2 \mathrm{H}$-azirines results in the formation of different products. It was shown that the $\mathrm{C}-\mathrm{N}$ bond cleavage is favored by thermal treatment due to the unusual length of this bond, $1,18,19$ while in general the $\mathrm{C}-\mathrm{C}$ bond breakage is the dominant pathway resulting from photoexcitation of $2 H$-azirines. ${ }^{5-7,20-23}$ In substituted $2 H$-azirines, the photochemical cleavage of the $\mathrm{C}-\mathrm{C}$ bond gives rise to dipolar species (nitrile ylides), which can subsequently react with 1,3dipolarophiles. This procedure has been widely used in the synthesis of a variety of five-membered heterocycles (cf., Scheme 1). ${ }^{5-7,24-27}$

\footnotetext{
* To whom correspondence should be addressed. E-mail: rfausto@ci.uc.pt

$\dagger$ University of Coimbra.

$\doteqdot$ Universidad de Buenos Aires.

$\S$ Jagiellonian University.
}

Recent quantum-chemical calculations shed some light on the above-mentioned observations. On the basis of complete active space self-consistent field (CASSCF) calculations, Klessinger and Borneman ${ }^{28,29}$ demonstrated that the photochemical formation of the nitrile ylide from the respective $2 \mathrm{H}$-azirine (by $\mathrm{C}-\mathrm{C}$ bond cleavage) occurs in an $n \pi^{*}$ singlet excited state and involves a barrierless conical intersection between the $S_{1}$ and $\mathrm{S}_{0}$ potential energy surfaces. The conclusions are in agreement with laser-pulse experiments showing that formation of the nitrile ylide from $2 \mathrm{H}$-phenylazirine or 3-(biphenyl-4-yl)- $2 \mathrm{H}$ azirine is an ultrafast process, as it can be achieved in $20 \mathrm{~ns}$ or shorter under laser-pulse excitation. ${ }^{25,30}$ On the contrary, the thermal $\mathrm{C}-\mathrm{C}$ bond breakage requires a high activation energy (ca. $230 \mathrm{~kJ} \mathrm{~mol}^{-1}$ ) and can only take place at high temperatures. $^{28,29}$ The $\mathrm{C}-\mathrm{N}$ bond cleavage, resulting in the formation of a ketene imine type product, is then the preferred thermal reaction. Nevertheless, the formation of azabutadienes as products resulting from thermal $\mathrm{C}-\mathrm{C}$ bond cleavage was observed during the pyrolysis of a series of 2-phenyl- or 3-phenyl- $2 \mathrm{H}$-azirines. ${ }^{4}$

Recently, Inui and Murata ${ }^{31-34}$ have shown that both $\mathrm{C}-\mathrm{C}$ and $\mathrm{C}-\mathrm{N}$ bonds can be cleaved upon photolysis of naphthylsubstituted $2 \mathrm{H}$-azirines isolated in cryogenic inert matrixes, depending on the excitation wavelength. They have proposed a mechanism for the photochemical rearrangement of 3-methyl2-(1-naphthyl)-2H-azirine into the corresponding ketene imine. This mechanism involves the cleavage of the $\mathrm{C}-\mathrm{N}$ bond. On the basis of the effects of media, substituents, sensitizers, and light intensity, they proposed that the rearrangement proceeds by a mechanism involving a vibrationally hot biradical generated upon the $\mathrm{C}-\mathrm{N}$ bond cleavage of the azirine ring in the $\mathrm{T}_{1}$ excited 
SCHEME 1: Photochemical $\mathrm{C}-\mathrm{C}$ Bond Cleavage of $2 \mathrm{H}$-Azirines and Subsequent Reaction of the 1,3-Dipole (nitrile ylide) with a 1,3-Dipolarophile $(X=Y)$

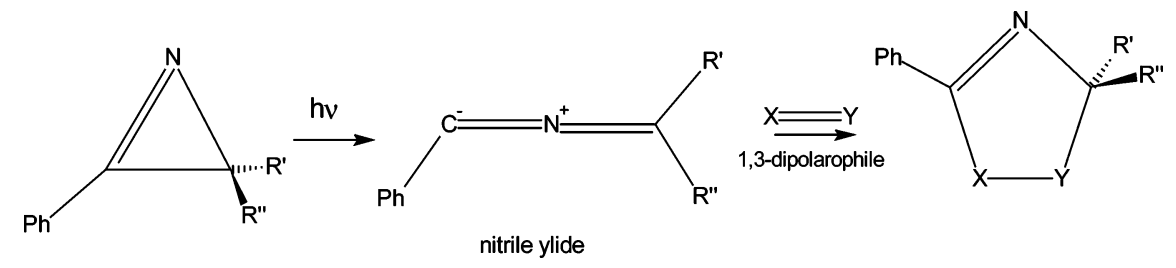

CHART 1: Methyl 3-Methyl-2H-azirine-2-carboxylate (MMAC)

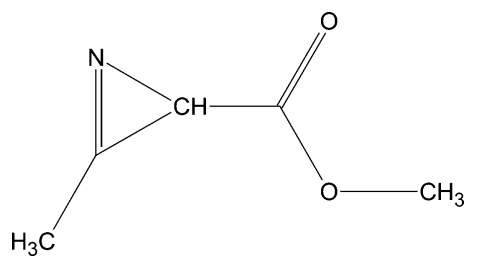

state. ${ }^{31-34}$ Our studies on methyl 2-chloro-3-methyl-2H-azirine2-carboxylate (MCMAC) ${ }^{35}$ have demonstrated that the $\mathrm{C}-\mathrm{N}$ bond can also be preferentially cleaved photochemically in the case of aliphatic $2 \mathrm{H}$-azirines bearing electron-withdrawing substituents in position C-2 (in MCMAC, the chlorine atom and the methoxycarbonyl group), which accelerate intersystem crossing toward the triplet state, thus favoring the irreversible cleavage of the $\mathrm{C}-\mathrm{N}$ bond. This result came in line with previous data, ${ }^{34}$ which also pointed out the significant influence of substituents present in the azirine ring on the relative efficiency of the $\mathrm{C}-\mathrm{C}$ and $\mathrm{C}-\mathrm{N}$ photocleavages. For example, when 3-methyl-2-(1-naphthyl)- $2 H$-azirine was irradiated with $\lambda>300 \mathrm{~nm}$ light, exclusive $\mathrm{C}-\mathrm{C}$ bond cleavage was observed, whereas replacement of the hydrogen atom on the naphthyl ring (in the para position relative to the $2 \mathrm{H}$-azirine substituent) by a bromine atom led to the formation of a mixture of products arising from the $\mathrm{C}-\mathrm{C}$ and $\mathrm{C}-\mathrm{N}$ bond cleavages. Moreover, when the strongly electron-withdrawing $\mathrm{NO}_{2}$ group was included in that position, the $\mathrm{C}-\mathrm{N}$ cleavage took place exclusively. ${ }^{34}$

To deepen our knowledge on the influence of the azirine ring substituents on the photochemically induced $\mathrm{C}-\mathrm{N}$ and $\mathrm{C}-\mathrm{C}$ bond cleavages, the $2 \mathrm{H}$-azirine, methyl 3-methyl- $2 \mathrm{H}$-azirine2-carboxylate (MMAC, Chart 1), was synthesized. Compared with MCMAC, this compound has the chlorine atom replaced by a hydrogen atom, whereas the methoxycarbonyl ester group is still present in the molecule. Comparison between the photochemical reactivity of the two compounds can then be used to shed light on the relative importance of the chlorine and methoxycarbonyl substituents in determining the preference for the $\mathrm{C}-\mathrm{N}$ bond photocleavage previously observed for $\mathrm{MC}$ MAC. ${ }^{35}$

The low-temperature matrix environment previously applied in the study of MCMAC is also used in the present investigation to allow for stabilization of the obtained photoproducts and reduction of the number of undesired cross reactions. The interpretation of the experimental results now obtained is also supported by extensive B3LYP/6-311++G(d,p) calculations, which enabled undertaking a detailed structural characterization of both the reactants and products of the studied photoreactions.

\section{Materials and Methods}

IR Spectroscopy. MMAC was synthesized as described elsewhere. ${ }^{36,37}$ The IR spectra were obtained using a Mattson (Infinity 60AR Series) Fourier transform infrared spectrometer, equipped with a deuterated triglycine sulfate (DTGS) detector and a $\mathrm{Ge} / \mathrm{KBr}$ beam splitter, with $0.5 \mathrm{~cm}^{-1}$ spectral resolution. To avoid interference from atmospheric $\mathrm{H}_{2} \mathrm{O}$ and $\mathrm{CO}_{2}$, a stream of dry nitrogen was continuously passed through the optical path of the spectrometer. The compound was placed in a specially designed doubly thermostatable Knudsen cell, whose compartments (sample container and valve nozzle compartments) were kept at $298 \mathrm{~K}$ during deposition of the matrix. Matrixes were prepared by co-deposition of MMAC vapors coming out of the Knudsen cell together with large excess of the matrix gas (argon N60 obtained from Air Liquide) onto the CsI substrate of the cryostat cooled to $10 \mathrm{~K}$. All experiments were performed using an APD Cryogenics closed-cycle helium refrigeration system with a DE-202A expander. After the compound was deposited, annealing experiments were performed until a temperature of $30 \mathrm{~K}$ was attained. Irradiation of the matrix was carried out with a $500 \mathrm{~W}$ mercury (xenon) lamp (Newport, Oriel Instruments) through the outer $\mathrm{KBr}$ window of the cryostat $(\lambda>235 \mathrm{~nm})$.

Computational Methodology. The DFT calculations were performed with the B3LYP density functional ${ }^{38,39}$ and the $6-311++\mathrm{G}(\mathrm{d}, \mathrm{p})$ basis set, using Gaussian98${ }^{40}$ and Gaussian03. ${ }^{41}$ Geometrical parameters were optimized using the Geometry Direct Inversion of the Invariant Subspace (GDIIS) method. ${ }^{42,43}$ The transition states for the conformational interconversion between pairs of MMAC conformers differing by internal rotation around the $\mathrm{C}_{2}-\mathrm{C}_{4}$ or $\mathrm{C}_{4}-\mathrm{O}_{10}$ bond (see Figure 1 for atom numbering) were computed using the Transit-Guided Quasi-Newton (STQN; QST3) method. ${ }^{44,45}$ Vibrational frequencies were calculated at the same level of theory, and the nature of the stationary points on the potential energy surface (PES) resulting from optimization was determined by inspection of the corresponding calculated Hessian matrix. The optimized structures of all conformers described in this study were confirmed to correspond to true minimum energy conformations.

The calculated harmonic frequencies were also used in the analysis of the experimental spectra. They were scaled down by a factor of 0.978 , to account mainly for anharmonicity effects and limitations of the basis set. Potential energy distributions (PEDs) of the normal modes were computed in terms of natural internal coordinates ${ }^{46}$ with the Gar2ped program. ${ }^{47}$

\section{Results and Discussion}

Geometries and Energies. Four different conformers $(\mathrm{Ct}$, $\mathrm{Cc}, \mathrm{Tt}$, and Tg; Figure 1) of MMAC were predicted to exist by the calculations. The notation for the conformers adopted in this study highlights the conformations defined by the $\mathrm{O}_{9}=\mathrm{C}_{4}-$ $\mathrm{O}_{10}-\mathrm{C}_{11}$ and $\mathrm{O}_{9}=\mathrm{C}_{4}-\mathrm{C}_{2}-\mathrm{H}_{15}$ dihedral angles, which are specified by capital and lower-case letters, respectively. The zero-point corrected energy, standard Gibbs energy, and relative abundance of the conformers are given in Table 1 . Note that the presence of a chiral carbon atom in the molecule, $\mathrm{C}_{2}$, implies the existence of two enantiomeric forms for each conformer. Nevertheless, because the two enantiomers are spectroscopically equivalent, in this paper, the discussion will be focused on a single form. 

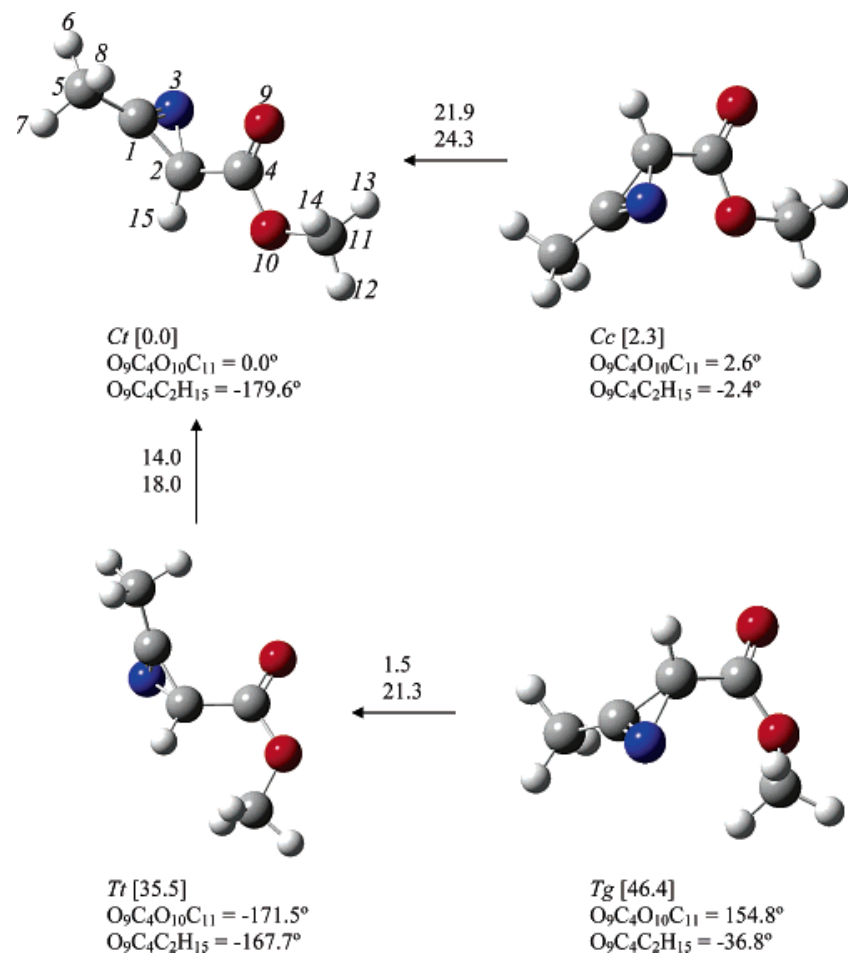

Figure 1. Optimized geometry of methyl 3-methyl-2H-azirine-2carboxylate conformers. The notation for the conformers adopted in this study highlights the conformations defined by the $\mathrm{O}_{9}=\mathrm{C}_{4}-\mathrm{O}_{10}-$ $\mathrm{C}_{11}$ and $\mathrm{O}_{9}=\mathrm{C}_{4}-\mathrm{C}_{2}-\mathrm{H}_{15}$ angles, which are specified by capital and lower-case letters, respectively. The values of zero-point corrected energy relative to the most stable conformer $\left(\mathrm{kJ} \mathrm{mol}^{-1}\right)$ are given in brackets, and the numbers above the arrows indicate the values of the barriers for conformational isomerization $\left(\mathrm{kJ} \mathrm{mol}^{-1}\right)$.

TABLE 1: Zero-point Corrected Energies $\left(\Delta E_{\text {corr }}\right.$, in kJ $\left.\mathrm{mol}^{-1}\right)$, Standard Gibbs Free Energies $\left(\Delta G\right.$, in $\left.\mathrm{kJ} \mathrm{mol}^{-1}\right)$, Dipole Moments ( $\mu$, in Debye), and Calculated Abundance $\left(A_{\text {calc }}\right.$, in percent) of Conformers of Methyl 3-Methyl-2H-azirine-2-carboxylate

\begin{tabular}{ccrrr}
\hline conformer $^{a}$ & $\mu$ & $\Delta E_{\text {corr }^{b}}$ & $\Delta G^{c}$ & $A_{\text {calc }}$ \\
\hline $\mathrm{Ct}$ & 3.1 & 0.0 & 0.0 & 71.4 \\
$\mathrm{Cc}$ & 3.7 & 2.3 & 2.3 & 28.6 \\
$\mathrm{Tt}$ & 4.7 & 35.5 & 35.1 & 0.0 \\
$\mathrm{Tg}$ & 4.0 & 46.4 & 45.4 & 0.0
\end{tabular}

${ }^{a}$ B3LYP/6-311++G(d,p); all structures have $C_{1}$ symmetry. ${ }^{b} E_{\text {corr }}$ $=-399.891442$ hartree for conformer Ct. ${ }^{c} G=-399.925569$ hartree for conformer $\mathrm{Ct}$ at $298.15 \mathrm{~K}$.

The most significant factor that determines the stability of MMAC conformers is the arrangement around the $\mathrm{C}-\mathrm{O}$ bond. As in the case of other carboxylic acids and esters, the cis (C) conformation is considerably more stable than the trans (T) arrangement. ${ }^{48-51}$ The trans-cis $(\mathrm{C}-\mathrm{O})$ energy differences in MMAC are similar to those found previously for MCMAC, where the $\mathrm{T}$ conformers were disfavored relative to the most stable conformer by more than $30 \mathrm{~kJ} \mathrm{~mol}^{-1} .35$ For MMAC, the energies of the $\mathrm{Tt}$ and $\mathrm{Tg}$ conformers (relative to the most stable conformer $(\mathrm{Ct})$ ) were predicted by the calculations to be 35.5 and $46.4 \mathrm{~kJ} \mathrm{~mol}^{-1}$. Taking into account the high relative energies of the two $\mathrm{T}$ forms, they can be assumed to be of no practical importance and will not be further considered in this study. The geometrical parameters for the two most stable forms are given in Table S1 of the Supporting Information.

The two low-energy conformers $(\mathrm{Ct}$ and $\mathrm{Cc})$ differ in the conformation defined by the $\mathrm{O}_{9}=\mathrm{C}_{4}-\mathrm{C}_{2}-\mathrm{H}_{15}$ dihedral angle. The $\mathrm{Ct}$ conformer was predicted to be more stable than the $\mathrm{Cc}$ form by $2.3 \mathrm{~kJ} \mathrm{~mol}^{-1}$. These conformers can be correlated with

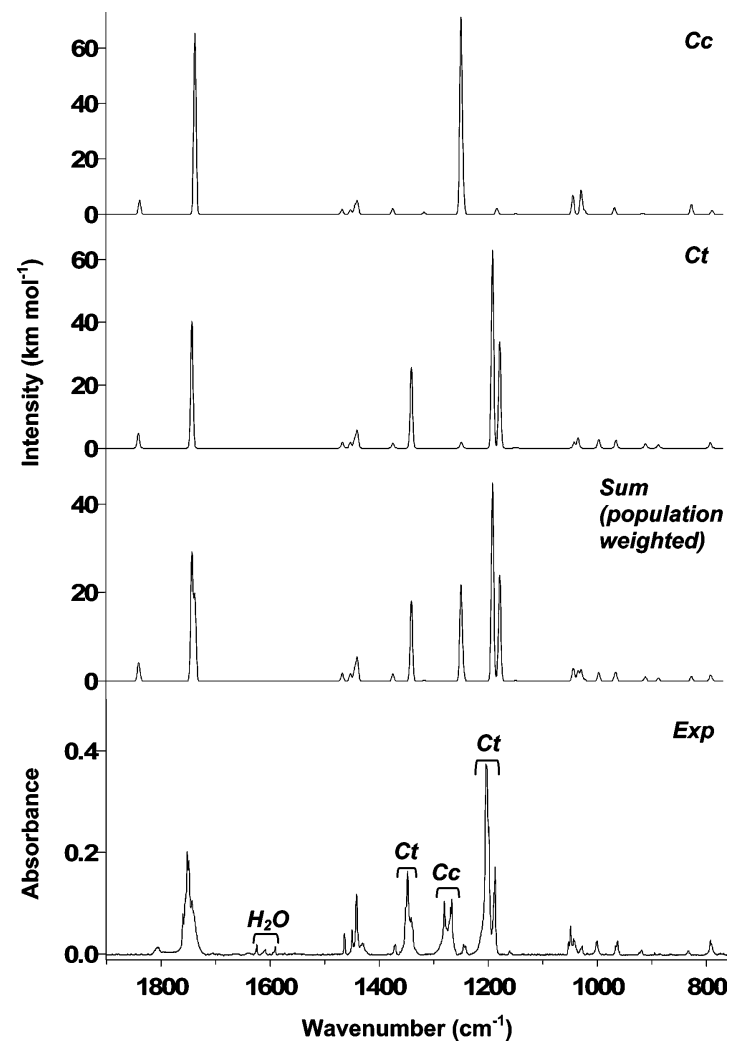

Figure 2. Comparison of the spectrum of matrix-isolated methyl 3-methyl-2H-azirine-2-carboxylate (Exp) along with the theoretical spectra of low-energy conformers $(\mathrm{Ct}$ and $\mathrm{Cc}$ ) and the sum spectrum (Sum) obtained by adding the calculated spectra of the two conformers normalized by their computed abundances at room temperature (71 and $29 \%$, respectively, for $\mathrm{Ct}$ and $\mathrm{Cc}$ ). Calculated wavenumbers were scaled by a factor of 0.978 .

the two most stable conformers of MCMAC. ${ }^{35}$ It must, however, be pointed out that in MCMAC the dipole moments of the two conformers differ considerably (Ct, 2.6 D; Cc, 4.9 D), while in MMAC the replacement of the electronegative chlorine atom by the hydrogen atom leads to a significant decrease in the dipolar moment of the $\mathrm{Cc}$ conformer and the dipole moments become nearly similar in the two forms $(\mathrm{Ct}, 3.1 \mathrm{D}$; Cc, $3.7 \mathrm{D}$; see Table 1). Therefore, contrary to what was found for MCMAC, in the case of MMAC, no additional stabilization of the higher-energy $\mathrm{Cc}$ conformer is expected to take place in the matrixes relative to the gas phase.

The energy barriers for $\mathrm{Cc} \rightarrow \mathrm{Ct}$ conversion were predicted by the calculations to be 21.9 and $24.3 \mathrm{~kJ} \mathrm{~mol}^{-1}$, depending on the direction of rotation around the $\mathrm{C}_{2}-\mathrm{C}_{4}$ bond. These barriers are then too high to be overcome by annealing of the argon matrixes up to the maximum possible work temperature (ca. $35 \mathrm{~K}$; above this temperature, the optical properties of the matrix strongly deteriorate and evaporation of the matrix occurs extensively). ${ }^{52}$ Therefore, no conformational conversion is expected to take place in the argon matrix. In addition, gasphase equilibrium populations can also be expected to be efficiently trapped in the matrix during deposition.

Vibrational Spectrum. The IR spectrum of matrix-isolated MMAC is presented in Figure 2 along with the calculated spectra of the two low-energy conformers and their sum spectrum weighted by their calculated gas-phase abundances at room temperature (ca. 71 and $29 \%$ for $\mathrm{Ct}$ and $\mathrm{Cc}$, respectively). The proposed band assignments are given in Table 2, while the whole set of calculated IR frequencies and intensities for these two conformers are provided as Supporting Information 
TABLE 2: Observed Frequencies for the $\mathrm{Ct}$ and Cc Conformers of Methyl 3-Methyl-2H-azirine-2-carboxylate in the Argon Matrix, Calculated Vibrational Frequencies, and Intensities of Normal Modes

\begin{tabular}{|c|c|c|c|c|c|c|c|c|c|c|c|}
\hline \multirow[b]{2}{*}{$\begin{array}{l}\text { approximate } \\
\text { description }^{a}\end{array}$} & \multirow[b]{2}{*}{ conformer } & \multicolumn{2}{|c|}{$\begin{array}{c}\text { calculated values } \\
\text { B3LYP/6-311++G(d,p) }\end{array}$} & \multicolumn{2}{|c|}{$\begin{array}{l}\operatorname{argon} \text { matrix } \\
(10 \mathrm{~K})\end{array}$} & \multirow[b]{2}{*}{$\begin{array}{l}\text { approximate } \\
\text { description }^{a}\end{array}$} & \multirow[b]{2}{*}{ conformer } & \multicolumn{2}{|c|}{$\begin{array}{c}\text { calculated values } \\
\text { B3LYP/6-311++G(d,p) }\end{array}$} & \multicolumn{2}{|c|}{$\begin{array}{l}\operatorname{argon} \text { matrix } \\
(10 \mathrm{~K})\end{array}$} \\
\hline & & $\begin{array}{c}v / \\
\mathrm{cm}^{-1 b}\end{array}$ & $\begin{array}{l}\mathrm{I} \\
\mathrm{km} \mathrm{mol}^{-1 c}\end{array}$ & $\begin{array}{c}v / \\
\mathrm{cm}^{-1}\end{array}$ & $I^{d}$ & & & $\frac{v /}{\mathrm{cm}^{-1 b}}$ & $\begin{array}{c}\mathrm{I} / \\
\mathrm{km} \mathrm{mol}^{-1 c}\end{array}$ & $\begin{array}{c}v / \\
\mathrm{cm}^{-1}\end{array}$ & $I^{d}$ \\
\hline$v\left(\mathrm{OCH}_{3}{ }^{\prime}\right)$ as & $\mathrm{Ct}$ & 3087 & 10.9 & \multirow{5}{*}{3036} & \multirow{5}{*}{ vW } & & & & & 1270 & $\mathrm{~m}, \mathrm{sh}$ \\
\hline$v \mathrm{C}-\mathrm{H}$ & $\mathrm{Cc}$ & 3087 & 5.5 & & & & & & & 1269 & $\mathrm{~m}$ \\
\hline$v\left(\mathrm{OCH}_{3}{ }^{\prime}\right)$ as & $\mathrm{Cc}$ & 3087 & 0.8 & & & & & & & 1266 & $\mathrm{~m}$ \\
\hline$v \mathrm{C}-\mathrm{H}$ & $\mathrm{Ct}$ & 3086 & 6.8 & & & $v \mathrm{C}-\mathrm{C} \alpha$ & $\mathrm{Ct}$ & 1246 & 6.8 & 1243 & vw \\
\hline$v\left(\mathrm{OCH}_{3}{ }^{\prime \prime}\right)$ as & $\mathrm{Ct}$ & 3054 & $13.3)$ & & & $v \mathrm{C}-\mathrm{C} \alpha$ & $\mathrm{Cc}$ & 1243 & 15.3 & 1241 & vw \\
\hline$v\left(\mathrm{OCH}_{3}{ }^{\prime \prime}\right)$ as & $\mathrm{Cc}$ & 3054 & 5.3 & \multirow{3}{*}{$\begin{array}{l}3010 \\
2994\end{array}$} & \multirow{3}{*}{$\begin{array}{l}\text { vw } \\
\text { vW }\end{array}$} & $v \mathrm{C}-\mathrm{O}, \gamma\left(\mathrm{OCH}_{3}\right)$ & $\mathrm{Ct}$ & 1188 & 239.1 & 1204 & vs \\
\hline$v\left(\mathrm{CCH}_{3}{ }^{\prime}\right)$ as & $\mathrm{Ct}$ & 3054 & 5.4 & & & & & & & 1202 & vs \\
\hline$v\left(\mathrm{CCH}_{3}{ }^{\prime}\right)$ as & $\mathrm{Cc}$ & 3054 & 2.2 & & & & & & & 1198 & vs \\
\hline$v\left(\mathrm{OCH}_{3}{ }^{\prime \prime}\right)$ as & $\mathrm{Ct}$ & 3032 & 2.0 & \multirow{2}{*}{2963} & \multirow{2}{*}{ w } & $\gamma\left(\mathrm{OCH}_{3}\right)$ & $\mathrm{Ct}$ & 1175 & 127.1 & 1189 & $\mathrm{~s}$ \\
\hline$v\left(\mathrm{CCH}_{3}{ }^{\prime \prime}\right)$ as & $\mathrm{Cc}$ & 3031 & 0.9 & & & $\gamma\left(\mathrm{OCH}_{3}\right)$ & $\mathrm{Cc}$ & 1180 & 3.4 & 1187 & s \\
\hline$v\left(\mathrm{OCH}_{3}\right) \mathrm{s}$ & $\mathrm{Ct}$ & 2983 & 23.2 & \multirow{2}{*}{2913} & \multirow[b]{2}{*}{ vw } & $\gamma\left(\mathrm{OCH}_{3}{ }^{\prime}\right)$ & $\mathrm{Cc}$ & 1146 & 0.3 & 1161 & vw \\
\hline$v\left(\mathrm{OCH}_{3}\right) \mathrm{s}$ & $\mathrm{Cc}$ & 2983 & 9.5 & & & $\gamma\left(\mathrm{OCH}_{3}{ }^{\prime}\right)$ & $\mathrm{Ct}$ & 1145 & 0.6 & 1052 & vw \\
\hline$v\left(\mathrm{CCH}_{3}\right) \mathrm{s}$ & $\mathrm{Ct}$ & 2970 & 5.0 & \multirow{2}{*}{2853} & \multirow{2}{*}{ VW } & $\gamma\left(\mathrm{CCH}_{3}{ }^{\prime}\right), v \mathrm{O}-\mathrm{CH}_{3}$ & $\mathrm{Cc}$ & 1040 & $10.4\}$ & \multirow{2}{*}{1049} & \multirow{2}{*}{$\mathrm{m}$} \\
\hline$v\left(\mathrm{CCH}_{3}\right) \mathrm{s}$ & $\mathrm{Cc}$ & 2970 & 2.0 & & & $\gamma\left(\mathrm{CCH}_{3}{ }^{\prime}\right), \delta \mathrm{C}-\mathrm{H}$ & $\mathrm{Ct}$ & 1038 & $7.1\}$ & & \\
\hline$v \mathrm{C}=\mathrm{N}$ & $\mathrm{Ct}$ & 1841 & 17.3 & $1807 ?$ & vw & $\gamma\left(\mathrm{CCH}_{3}^{\prime}\right)$ & $\mathrm{Ct}$ & 1031 & 11.9 & 1043 & vw \\
\hline$v \mathrm{C}=\mathrm{N}$ & $\mathrm{Cc}$ & 1839 & 7.8 & $1804 ?$ & vw & & & & & 1041 & vw \\
\hline \multirow[t]{4}{*}{$v \mathrm{C}=\mathrm{O}$} & \multirow[t]{4}{*}{$\mathrm{Ct}$} & 1742 & 152.2 & 1760 & $\mathrm{~m}$ & $v \mathrm{O}-\mathrm{CH}_{3}$ & $\mathrm{Cc}$ & 1025 & $13.4\}$ & & \\
\hline & & & & 1755 & $\mathrm{~s}, \mathrm{sh}^{e}$ & $\gamma\left(\mathrm{CCH}_{3}{ }^{\prime}\right)$ & $\mathrm{Cc}$ & 1019 & $2.1\}$ & 1027 & W \\
\hline & & & & 1752 & $\mathrm{~s}$ & $v \mathrm{O}-\mathrm{CH}_{3}, \delta \mathrm{C}-\mathrm{H}$ & $\mathrm{Ct}$ & 993 & 10.4 & 1001 & w \\
\hline & & & & 1749 & $\mathrm{~s}$ & & & & & 999 & w \\
\hline$v \mathrm{C}=\mathrm{O}$ & $\mathrm{Cc}$ & 1736 & 100.7 & 1743 & $\mathrm{~m}$ & $\delta \mathrm{C}-\mathrm{H}$ & $\mathrm{Cc}$ & 964 & 3.7 & 968 & w, sh \\
\hline & & & & 1739 & $\mathrm{~m}, \mathrm{sh}$ & $\delta \mathrm{C}-\mathrm{H}$ & $\mathrm{Ct}$ & 961 & 9.1 & 966 & w \\
\hline & & & & 1734 & w, sh & & & & & 962 & w \\
\hline$\delta\left(\mathrm{OCH}_{3}{ }^{\prime \prime}\right)$ as & $\mathrm{Cc}$ & 1466 & 2.6 & & & & & & & 959 & vw \\
\hline$\delta\left(\mathrm{OCH}_{3}{ }^{\prime \prime}\right)$ as & $\mathrm{Ct}$ & 1465 & 7.0 & 1463 & W & $v \mathrm{C}-\mathrm{CH}_{3}$ & $\mathrm{Cc}$ & 911 & 0.5 & 923 & vw \\
\hline$\delta\left(\mathrm{OCH}_{3}^{\prime}\right)$ as & $\mathrm{Ct}$ & 1450 & $6.7\}$ & & & $v \mathrm{O}-\mathrm{CH}_{3}, v \mathrm{C}-\mathrm{O}$ & $\mathrm{Ct}$ & 907 & 5.0 & 918 & vw \\
\hline$\delta\left(\mathrm{OCH}_{3}^{\prime}\right)$ as & $\mathrm{Cc}$ & 1450 & $2.5\}$ & 1449 & W & $v \mathrm{C}-\mathrm{N}, v \mathrm{C}-\mathrm{CH}_{3}$ & $\mathrm{Ct}$ & 883 & 3.8 & 894 & vw \\
\hline$\delta\left(\mathrm{CCH}_{3}{ }^{\prime \prime}\right)$ as & $\mathrm{Ct}$ & 1442 & 9.7 & 1441 & $\mathrm{~m}$ & $v \mathrm{C}-\mathrm{O}$ & $\mathrm{Cc}$ & 822 & 5.4 & 832 & vw \\
\hline$\delta\left(\mathrm{CCH}_{3}{ }^{\prime \prime}\right)$ as & $\mathrm{Cc}$ & 1442 & 4.0 & 1440 & $\mathrm{~m}, \mathrm{sh}$ & $\gamma \mathrm{C}=\mathrm{O}$ & $\mathrm{Ct}$ & 787 & 6.2 & 792 & $\mathrm{w}$ \\
\hline$\delta\left(\mathrm{CCH}_{3}{ }^{\prime}\right)$ as & $\mathrm{Ct}$ & 1439 & 4.6 & 1434 & vw & $\gamma \mathrm{C}=\mathrm{O}$ & $\mathrm{Cc}$ & 784 & 2.1 & 789 & w \\
\hline$\delta\left(\mathrm{OCH}_{3}\right) \mathrm{s}$ & $\mathrm{Cc}$ & 1439 & 0.9 & 1430 & vw & & $?$ & & & 749 & $\mathrm{~s}$ \\
\hline$\delta\left(\mathrm{OCH}_{3}\right) \mathrm{s}$ & $\mathrm{Ct}$ & 1437 & $17.1\}$ & 1428 & & & $?$ & & & 747 & $\mathrm{~m}$ \\
\hline$\delta\left(\mathrm{CCH}_{3}{ }^{\prime}\right)$ as & $\mathrm{Cc}$ & 1437 & 6.4 & 1428 & VW & & $?$ & & & 745 & vw \\
\hline$\delta\left(\mathrm{CCH}_{3}\right) \mathrm{s}$ & $\mathrm{Cc}$ & 1372 & 3.1 & 1372 & $\mathrm{vw}$ & $\begin{array}{l}\delta \mathrm{O}=\mathrm{C}-\mathrm{O}, \gamma \mathrm{C}-\mathrm{N} \\
\mathrm{w} \mathrm{C}=\mathrm{O}, \delta \mathrm{COC}\end{array}$ & $\mathrm{Ct}$ & 707 & 9.8 & 719 & $\mathrm{vw}$ \\
\hline$\delta\left(\mathrm{CCH}_{3}\right) \mathrm{s}$ & $\mathrm{Ct}$ & 1372 & 5.5 & 1370 & vw & & & & & 715 & $\mathrm{~W}$ \\
\hline$\gamma \mathrm{C}-\mathrm{H}$ & $\mathrm{Ct}$ & 1338 & 96.9 & 1351 & $\mathrm{~m}, \mathrm{sh}$ & & & & & 712 & vw \\
\hline & & & & 1348 & $\mathrm{~s}$ & & & & & 709 & vw \\
\hline & & & & 1340 & $\mathrm{~m}$ & ${ }_{\mathrm{w} \mathrm{C}}=\mathrm{O}, \gamma \mathrm{C}-\mathrm{N}$ & $\mathrm{Cc}$ & 675 & 2.9 & 688 & vw \\
\hline$\gamma \mathrm{C}-\mathrm{H}$ & $\mathrm{Cc}$ & 1314 & 1.1 & 1338 & $\mathrm{~m}, \mathrm{sh}$ & $v \mathrm{C}-\mathrm{N}$ & $\mathrm{Ct}$ & 639 & 5.6 & 641 & vw \\
\hline$v \mathrm{C}-\mathrm{O}, v \mathrm{C}-\mathrm{C}$ & $\mathrm{Cc}$ & 1247 & 106.9 & 1280 & $\mathrm{~m}$ & $v \mathrm{C}-\mathrm{N}$ & $\mathrm{Cc}$ & 636 & 2.6 & 636 & $\mathrm{vw}$ \\
\hline
\end{tabular}

${ }^{a} \nu$, bond stretching; $\delta$, in-plane bending; $\gamma$, out-of-plane bending; w, wagging, as, asymmetric; s, symmetric. ${ }^{b}$ Scale factor $=0.978 .{ }^{c}$ Calculated intensities were weighted by the population factor $(T=298 \mathrm{~K})$ for each conformer $(0.71 \mathrm{for} \mathrm{Ct}$ and 0.29 for $\mathrm{Cc}) .{ }^{d} \mathrm{vs}, \mathrm{s}, \mathrm{m}, \mathrm{w}$, and vw denote bands of very strong, strong, medium, weak, and very weak intensity, respectively. ${ }^{e}$ Shoulder.

(Tables S2-S4). Although the bands of the two conformers can be expected to overlap significantly, the absorptions in the $1400-1180 \mathrm{~cm}^{-1}$ range allow for the unequivocal spectroscopic identification of both forms (cf., Figure 2). For example, the set of vibrations in the $1280-1260 \mathrm{~cm}^{-1}$ range can doubtlessly be attributed to the Cc conformer, while the groups of absorptions in the $1370-1330$ and $1205-1185 \mathrm{~cm}^{-1}$ regions may be assigned predominantly to the $\mathrm{Ct}$ conformer, since only very low intensity bands of the $\mathrm{Cc}$ form are predicted by calculations to lie near these spectral regions (see Table 2). Similar to what was found for MCMAC, ${ }^{35}$ considerable band splitting is observed for both conformers of MMAC, due to trapping of the solute molecules in different matrix sites.

In agreement with the theoretical predictions, no conformational interconversion was observed upon annealing of the matrix up to $30 \mathrm{~K}$, the (minor) observed spectral changes with temperature being exclusively due to site-conversion. Furthermore, also in agreement with our expectations, the calculated room temperature gas-phase equilibrium conformational population ratio could be efficiently frozen in the matrix, as it is clearly shown in Figure 2 (compare the experimental spectrum with the population-weighted theoretical sum spectrum shown in this figure).

Photochemistry of Matrix-isolated MMAC. The in situ broadband irradiation $(\lambda>235 \mathrm{~nm})$ of matrix-isolated MMAC resulted in the single-exponential decrease of the bands attributed to each conformer of the compound (Figure 3) with the simultaneous appearance of new absorptions (Figure 4), with the latter being particularly intense in the 2400-2000, 17401710 , and $1220-1210 \mathrm{~cm}^{-1}$ spectral regions (cf., Figures 4-6).

The kinetics of the reaction is of first order, with a slight preference for decomposition of conformer Cc (see Figure 3). Two reactions were observed for MMAC, leading to the formation of the nitrile ylide (P1) and ketene imine (P2) type products, which result from the $\mathrm{C}-\mathrm{C}$ and $\mathrm{C}-\mathrm{N}$ bond cleavages, respectively. The comparison of the positions and relative intensities of the bands appearing in the spectra of the irradiated matrix with the calculated spectra of the two possible conformers of both nitrile ylide (P1) and 3-methoxycarbonyl-1-methylketene imine (P2) (see Figures 4-6) allowed for the assignment of 


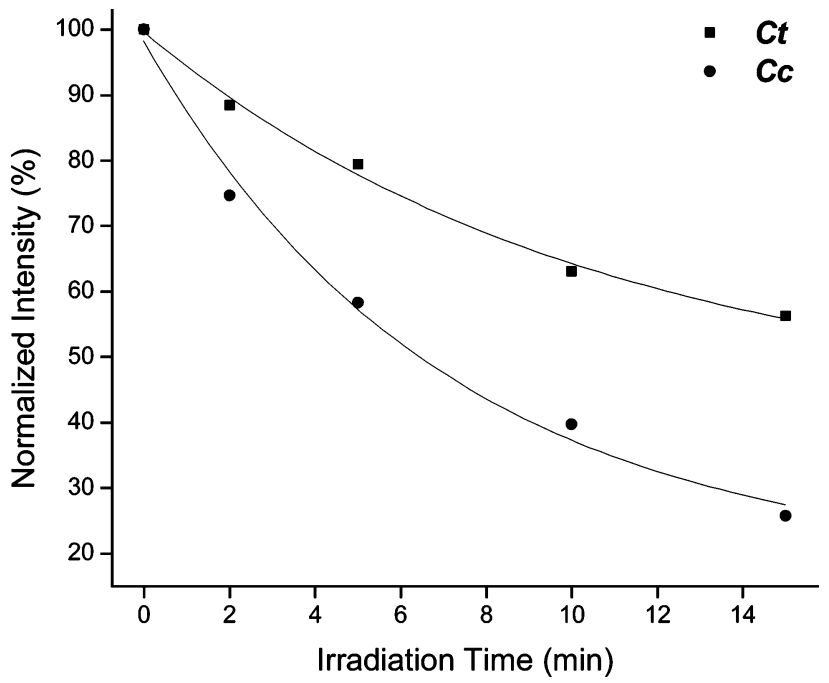

Figure 3. Decrease of intensity of methyl 3-methyl- $2 \mathrm{H}$-azirine-2carboxylate absorptions due to irradiation with $\lambda>235 \mathrm{~nm}$. The sets of bands at 1370-1330 and 1280-1260 $\mathrm{cm}^{-1}$ were chosen for $\mathrm{Ct}$ and $\mathrm{Cc}$, respectively. The bands were normalized by the corresponding calculated intensities, and the normalized intensity in the as-deposited matrix was assumed to be $100 \%$.

most of the observed features ascribable to the photoproducts, as detailed in Table 3. The whole set of calculated frequencies and IR intensities for P1 and P2 are given in Tables S5 and S6 (Supporting Information).

Among all bands of the photoproducts, the broad band centered at ca. $2077 \mathrm{~cm}^{-1}$ was the first to be clearly observed in the spectrum of the irradiated matrix, together with bands at around $2340 \mathrm{~cm}^{-1}$ due to associated carbon dioxide (Figure 5). These bands are already clearly defined after 2 min of irradiation, while it was also evident that other features were growing in the $2140-2080 \mathrm{~cm}^{-1}$ region, though not appearing as clearly defined bands. After another 3 min of irradiation, the intensity of bands due to photoproducts increased in such a way that bands at 2138 (due to carbon monoxide), 2126, 2122, 2114, 2112, 2092, and $2082 \mathrm{~cm}^{-1}$ also became well defined. Subsequent irradiation of the matrix brought further increase of all the above-mentioned bands, with the bands at 2092 and 2082 $\mathrm{cm}^{-1}$ as well as those due to $\mathrm{CO}$ and $\mathrm{CO}_{2}$ exhibiting the most pronounced growth in the later stages of irradiation.

As the band centered at $2077 \mathrm{~cm}^{-1}$ appears immediately after 2 min of irradiation, it is concluded that it has to be associated with one of the primary photoproducts $-\mathrm{P} 1$ or P2. According to the calculations, it shall be attributed to P1 (calculated frequencies for $\mathrm{Ct}$ and $\mathrm{Cc}$ conformers, 2073 and $2055 \mathrm{~cm}^{-1}$, respectively), which is formed by photocleavage of the $\mathrm{C}-\mathrm{C}$ bond in the "classical" way for aliphatic $2 \mathrm{H}$-azirines (see Figure 7). On the other hand, the bands observed in the 2126-2112 $\mathrm{cm}^{-1}$ region originated in $\mathrm{P} 2$ (calculated frequencies, 2116 and $2110 \mathrm{~cm}^{-1}$, for $\mathrm{Ct}$ and $\mathrm{Cc}$ conformers, respectively) and reveal that the unusual $\mathrm{C}-\mathrm{N}$ bond cleavage also took place during irradiation. The fact that these bands became well defined at a slightly longer time of irradiation is correlated with simultaneous observation of the bands due to $\mathrm{CO}$ and $\mathrm{CO}_{2}$, as well as the above-mentioned bands at 2092 and $2082 \mathrm{~cm}^{-1}$. Indeed, the appearance of bands due to carbon monoxide and carbon dioxide is unequivocal evidence that, besides the formation of P1 and $\mathrm{P} 2$, additional photochemical reactions took place in the matrix. The comparison of the calculated spectra of the decarboxylation and decarbonylation products of $\mathrm{P} 1$ and $\mathrm{P} 2$ with the experimental data indicated that only P2 undergoes subsequent

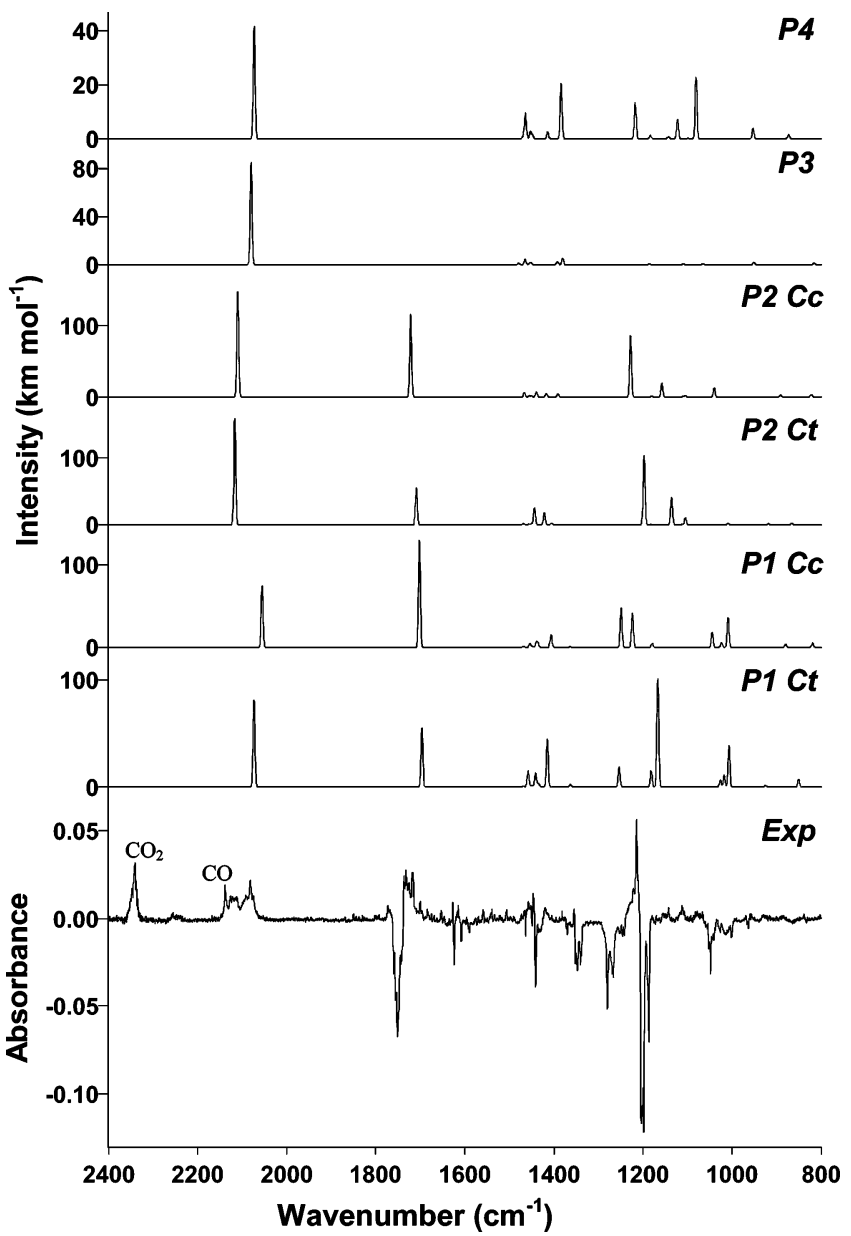

Figure 4. Comparison of the difference (irradiated minus as-deposited) spectrum of matrix-isolated methyl 3-methyl- $2 \mathrm{H}$-azirine-2-carboxylate after $15 \mathrm{~min}$ of irradiation with $\lambda>235 \mathrm{~nm}$ (Exp) along with the theoretical spectra of the predicted photoproducts. P1, P2, P3, and P4 denote nitrile ylide, 3-methoxycarbonyl-1-methylketene imine, 1,3dimethylketene imine, and 3-methoxy-1-methylketene imine, respectively, and $\mathrm{Ct}$ and $\mathrm{Cc}$ indicate the conformations around the $\mathrm{C}-\mathrm{O}$ and $\mathrm{C}-\mathrm{C}_{\alpha}$ bonds, respectively, following the notation used for MMAC. Calculated wavenumbers were scaled by a factor of 0.978 .

reactions: decarboxylation, with the formation of 1,3-dimethylketene imine (P3), and decarbonylation, with the production of 3-methoxy-1-methylketene imine (P4). The bands at 2082 and $2092 \mathrm{~cm}^{-1}$, which grew more during the late stages of excitation (along with the absorptions attributed to carbon monoxide and carbon dioxide), are then ascribed to the products of decarboxylation and decarbonylation of P2 (P3 and P4, respectively; calculated frequencies, 2073 and $2080 \mathrm{~cm}^{-1}$ ), which shall accumulate as final photoproducts for long irradiation times. Note that these two secondary processes start early, as soon as P2 starts to be formed, justifying the greater difficulty in observing well-defined features due to this product when compared with the nonreactive P1 species.

The whole proposed scheme for photochemical reactions of matrix-isolated monomeric MMAC is summarized in Figure 7. Note that the reactivity of the primary photoproducts was found to be different for MMAC and the previously studied analogue chloro-substituted compound, MCMAC. ${ }^{35}$ In MCMAC, both primary photoproducts (equivalent to $\mathrm{P} 1$ and $\mathrm{P} 2$ ) were found to take part in secondary photoreactions, with $\mathrm{P} 1$ undergoing decarboxylation and P2 decarbonylation. For MMAC, as described above, only P2 undergoes subsequent photoreactions. The lack of any secondary photoproduct resulting from decom- 

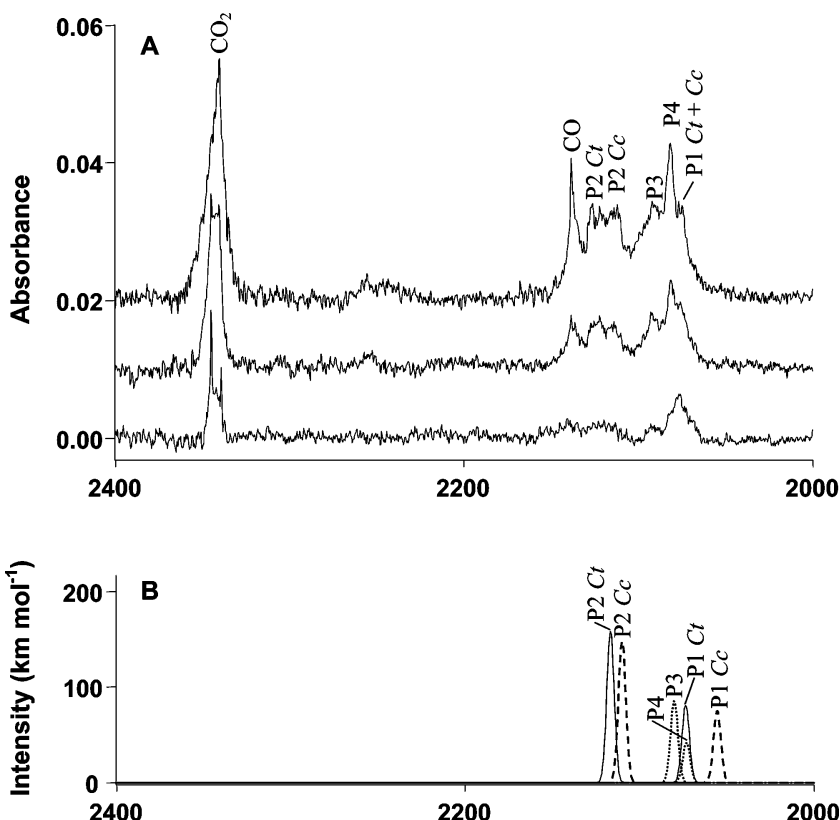

Wavenumber $\left(\mathrm{cm}^{-1}\right)$

Figure 5. (A) Spectra of matrix-isolated methyl 3-methyl-2H-azirine2-carboxylate after 2 (the bottom-most line), 5 (the middle line), and 15 (the upper-most line) min of irradiation with $\lambda>235 \mathrm{~nm}$ in the $2400-2000 \mathrm{~cm}^{-1}$ range. The spectra obtained after irradiation were shifted in absorbance scale for clarity. (B) B3LYP/6-311++G(d,p) calculated spectra of photoproducts in the same spectral region. Calculated wavenumbers were scaled by a factor of 0.978 .
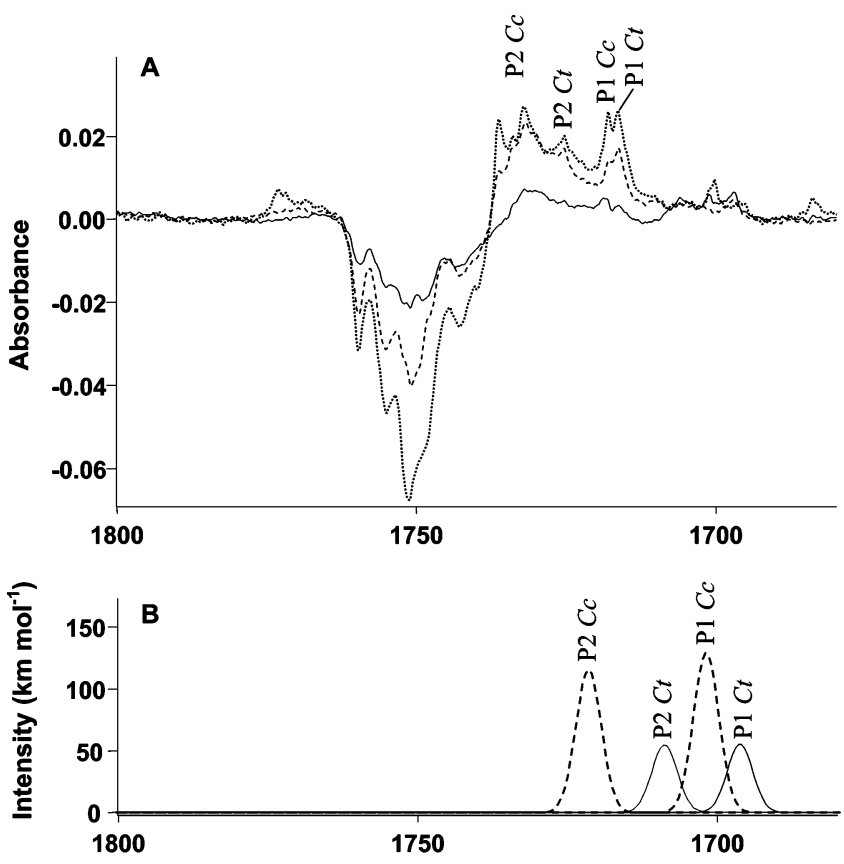

Wavenumber $\left(\mathbf{c m}^{-1}\right)$

Figure 6. (A) Difference spectra (irradiated minus as-deposited spectra) of matrix-isolated methyl 3-methyl-2H-azirine-2-carboxylate after 2 (the solid line), 5 (the dashed line), and 15 (the dotted line) min of irradiation with $\lambda>235 \mathrm{~nm}$ in the $1800-1680 \mathrm{~cm}^{-1}$ range. (B) B3LYP/6$311++\mathrm{G}(\mathrm{d}, \mathrm{p})$ calculated spectra of $\mathrm{P} 1$ and $\mathrm{P} 2$ in the same spectral region. Calculated wavenumbers were scaled by a factor of 0.978 .

position of P1 reveals the higher photostability of this species when compared with the corresponding photoproduct obtained from MCMAC. On the other hand, after the same irradiation
TABLE 3: Observed and Calculated IR Bands of Products of Photoreaction of Methyl 3-methyl-2H-azirine-2-carboxylate in the Argon Matrix

\begin{tabular}{|c|c|c|c|c|}
\hline \multirow[b]{2}{*}{ product } & \multicolumn{2}{|c|}{$\begin{array}{c}\text { calculated values } \\
\text { B3LYP/6-311++G(d,p) }\end{array}$} & \multicolumn{2}{|c|}{ argon matrix $(10 \mathrm{~K})$} \\
\hline & $v / \mathrm{cm}^{-1 a}$ & $I / \mathrm{km} \mathrm{mol}^{-1}$ & $v / \mathrm{cm}^{-1}$ & $I^{b}$ \\
\hline$?$ & & & 3705 & $\mathrm{vw}$ \\
\hline$?$ & & & 3522 & vw \\
\hline P3 & 2943 & 75.6 & 2938 & wv \\
\hline $\mathrm{CO}_{2}$ & & & 2341 & $\mathrm{~s}$ \\
\hline $\mathrm{CO}$ & & & $2139,2137,2135$ & $\mathrm{~m}, \mathrm{~m}, \mathrm{sh}$ \\
\hline $\mathrm{P} 2 \mathrm{Ct}$ & 2116 & 842.0 & 2126,2122 & $\mathrm{~m}, \mathrm{~m}$ \\
\hline $\mathrm{P} 2 \mathrm{Cc}$ & 2110 & 789.5 & 2114,2112 & $\mathrm{~m}, \mathrm{~m}$ \\
\hline P3 & 2080 & 453.9 & 2092 & $\mathrm{~m}$ \\
\hline P4 & 2073 & 222.1 & 2082 & $\mathrm{~m}$ \\
\hline $\mathrm{P} 1 \mathrm{Ct}$ & 2073 & 430.7 r & $2077 d$ & \\
\hline $\mathrm{P} 1 \mathrm{Cc}$ & 2055 & $398.4\}$ & $20 / \pi^{a}$ & $\mathrm{~m}$ \\
\hline ? & & & 1850 & $\mathrm{vw}$ \\
\hline ? & & & 1774 & $\mathrm{w}$ \\
\hline $\mathrm{P} 2 \mathrm{Cc}$ & 1722 & 614.0 & $1736,1734,1732$ & $\mathrm{~s}, \mathrm{~s}, \mathrm{~s}$ \\
\hline $\mathrm{P} 2 \mathrm{Ct}$ & 1709 & 291.4 & 1725 & $\mathrm{~s}$ \\
\hline $\mathrm{P} 1 \mathrm{Cc}$ & 1702 & 687.9 & 1718 & $\mathrm{~s}$ \\
\hline $\mathrm{P} 1 \mathrm{Ct}$ & 1696 & 294.7 & 1716 & $\mathrm{~s}$ \\
\hline ? & & & 1627 & $\mathrm{~s}$ \\
\hline ? & & & 1615 & $\mathrm{~m}$ \\
\hline ? & & & 1596,1595 & $\mathrm{vw}$ \\
\hline $\mathrm{P} 1 \mathrm{Ct}$ & 1458 & 78.6 & 1467 & $\mathrm{w}$ \\
\hline $\mathrm{P} 2 \mathrm{Ct}$ & 1443 & 133.6 & 1446 & $\mathrm{~s}$ \\
\hline $\mathrm{P} 2 \mathrm{Ct}$ & 1421 & 95.6 & 1421 & $\mathrm{w}$ \\
\hline $\mathrm{P} 1 \mathrm{Ct}$ & 1414 & 235.1 & 1414 & $\mathrm{vw}$ \\
\hline $\mathrm{P} 1 \mathrm{Cc}$ & 1406 & 80.4 & 1404 & $\mathrm{vw}$ \\
\hline P4 & 1383 & 108.9 & 1381 & $\mathrm{w}$ \\
\hline ? & & & 1354 & $\mathrm{~m}$ \\
\hline $\mathrm{P} 1 \mathrm{Ct}$ & 1254 & 97.0 & 1248 & $\mathrm{w}$ \\
\hline $\mathrm{P} 1 \mathrm{Cc}$ & 1249 & 252.1 & 1244 & $\mathrm{w}$ \\
\hline $\mathrm{P} 2 \mathrm{Cc}$ & 1228 & $455.1\}$ & & \\
\hline $\mathrm{P} 1 \mathrm{Cc}$ & 1224 & $217.5\}$ & 1222 & $\mathrm{~m}$ \\
\hline $\mathrm{P} 2 \mathrm{Ct}$ & 1198 & 551.3 & 1214 & vs \\
\hline $\mathrm{P} 1 \mathrm{Ct}$ & 1182 & 79.1 & 1212 & vs \\
\hline $\mathrm{P} 1 \mathrm{Ct}$ & 1167 & 538.8 & 1206 & $\mathrm{~m}$ \\
\hline $\mathrm{P} 2 \mathrm{Cc}$ & 1158 & 102.4 & 1143 & w \\
\hline $\mathrm{P} 2 \mathrm{Ct}$ & 1136 & 219.1 & 1111 & w \\
\hline P4 & 1081 & 122.5 & 1065 & vw \\
\hline $\mathrm{P} 1 \mathrm{Cc}$ & 1009 & 190.3 & 1010 & \\
\hline $\mathrm{P} 1 \mathrm{Ct}$ & 1007 & 206.5 & 1010 & vw \\
\hline
\end{tabular}

${ }^{a}$ Scale factor $=0.978 .{ }^{b} \mathrm{vs}, \mathrm{s}, \mathrm{m}, \mathrm{w}$, and vw denote bands of very strong, strong, medium, weak, and very weak intensity, respectively. ${ }^{c}$ Shoulder. ${ }^{d}$ We tentatively assign both conformers of P1 to this band. However, it is also possible that $\mathrm{P} 1 \mathrm{Ct}$ contributes to the band observed at $2082 \mathrm{~cm}^{-1}$.

time, a significantly higher relative intensity of the bands due to carbon monoxide (around $2138 \mathrm{~cm}^{-1}$ ) and associated molecules of carbon dioxide (in the range 2345-2341 $\mathrm{cm}^{-1}$ ) -when compared with the bands of the primary photoproducts-was observed in the case of MMAC. This result shows the greater facility of the $\mathrm{P} 2$ photoproduct obtained from MMAC to decompose upon irradiation when compared with the corresponding photoproduct of MCMAC.

For MMAC, the precise quantitative comparison of the amounts of the photoproduced P1 and P2 was not possible due to the considerable overlap of bands attributed to these species and also because of the occurrence of the above-mentioned secondary processes. Nevertheless, taking into consideration the calculated intensities for both photoproducts (cf., Table 3), the analysis of the $1800-1700 \mathrm{~cm}^{-1}$ range (cf., Figure 6) doubtlessly shows that the $\mathrm{C}-\mathrm{N}$ bond cleavage process is favored over the $\mathrm{C}-\mathrm{C}$ one. The set of bands at ca. $1734 \mathrm{~cm}^{-1}$, increasing upon irradiation, was assigned to the vibration which is theoretically predicted to occur at $1722 \mathrm{~cm}^{-1}$ (P2 Cc), and the bands at 1725,1718 , and $1716 \mathrm{~cm}^{-1}$ were attributed to the 


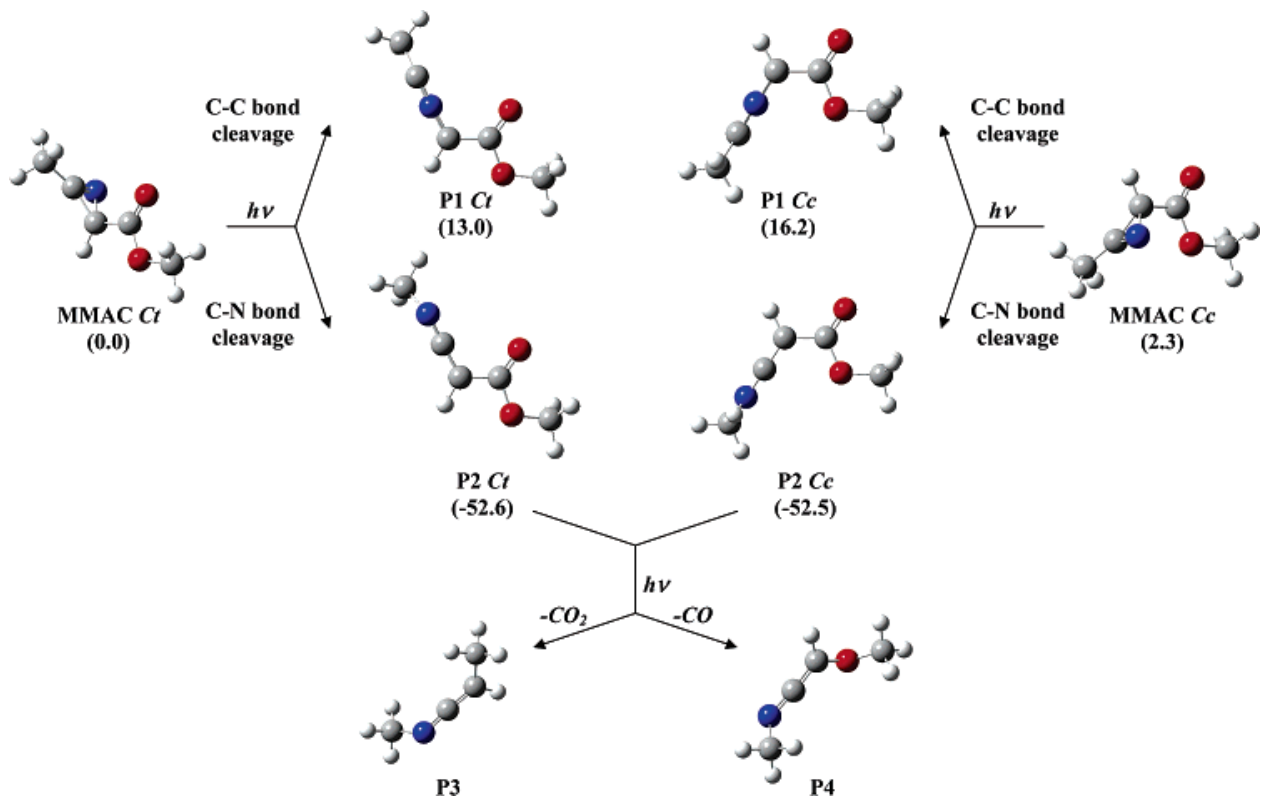

Figure 7. Proposed reaction pathways resulting from irradiation of methyl 3-methyl- $2 H$-azirine-2-carboxylate with $\lambda>235 \mathrm{~nm}$. Zero-point corrected energies (in kJ mol${ }^{-1}$ ) of primary photoproducts (P1 and P2) and reactants relative to the most stable conformer of MMAC are given in parentheses.

calculated bands at 1709 (P2 Ct), 1702 (P1 Ct), and 1696 (P1 Cc) $\mathrm{cm}^{-1}$, respectively. As the computed intensities of the bands due to the $\mathrm{Ct}$ and $\mathrm{Cc}$ conformers are comparable, the more intense absorptions of $\mathrm{P} 2$ indicate that photoproduction of this species is preferred over formation of $\mathrm{P} 1$, even though it further reacts to give rise to the secondary products, $\mathrm{P} 3$ and $\mathrm{P} 4$, as described above. The same qualitative conclusion can also be extracted by analysis of other spectral regions, in particular, the $2200-2000 \mathrm{~cm}^{-1}$ spectral range, depicted in Figure 5.

Application of cutoff filters (at $\lambda>375,337$, and $285 \mathrm{~nm}$ ) resulted in the lack of photochemical reaction, in agreement with time-dependent DFT calculations (TD-DFT, B3LYP/6$311++\mathrm{G}(\mathrm{d}, \mathrm{p})$ ), which predict the $\mathrm{S}_{0} \rightarrow \mathrm{S}_{1}$ transition at 226.0 and $230.8 \mathrm{~nm}$ for the $\mathrm{Ct}$ and $\mathrm{Cc}$ conformers of MMAC, respectively. Note that the substitution of the chlorine atom in MCMAC by the hydrogen atom in MMAC slightly increases the $S_{0} \rightarrow S_{1}$ energy gap (for MCMAC the $S_{0} \rightarrow S_{1}$ energy gap was predicted to be 240.5 and $243.2 \mathrm{~nm}$ for the $\mathrm{Ct}$ and $\mathrm{Cc}$ conformers, respectively).

As it was discussed in the Introduction, the $\mathrm{C}-\mathrm{N}$ bond cleavage, unusual for aliphatic $2 \mathrm{H}$-azirines, was previously observed for MCMAC and attributed to the presence of two electron-withdrawing substituents on the azirine ring (methoxycarbonyl group and chlorine atom), which accelerate the intersystem crossing toward the triplet state and, in this way, the $\mathrm{C}-\mathrm{N}$ bond breakage. ${ }^{35}$ The $\mathrm{P} 2 / \mathrm{P} 1$ photoproducts' ratio was in that case estimated to be ca. 2:1. Although as mentioned above no precise quantitative information could be obtained for MMAC, the results now obtained clearly showed that the $\mathrm{C}-\mathrm{N}$ bond cleavage is also favored over the $\mathrm{C}-\mathrm{C}$ bond breakage for this compound. The lack of the chlorine atom in MMAC may be at least partially compensated for by the significantly higher stabilization of $\mathrm{P} 2$ relative to MMAC (ca. $-52 \mathrm{~kJ} \mathrm{~mol}^{-1}$ ) in comparison with the corresponding photoproduct obtained from MCMAC (ca. $-26 \mathrm{~kJ} \mathrm{~mol}^{-1}{ }^{35}$ ). The obtained results show also that the methoxycarbonyl group plays the most important role in determining the photochemical behavior of the abovementioned aliphatic $2 \mathrm{H}$-azirines, in particular the preference for the unusual $\mathrm{C}-\mathrm{N}$ bond cleavage over the "classic" $\mathrm{C}-\mathrm{C}$ bond cleavage they exhibit.

\section{Conclusions}

To widen further our understanding on the influence of substituents on the photochemistry of aliphatic $2 \mathrm{H}$-azirines, methyl 3-methyl-2H-azirine-2-carboxylate (MMAC) has been synthesized and its structure and photochemical behavior investigated by matrix-isolation IR spectroscopy and DFT calculations.

Two conformers of MMAC were efficiently trapped in an argon matrix at $10 \mathrm{~K}$ ( $\mathrm{Ct}$ and $\mathrm{Cc}$ forms) in agreement with the theoretical calculations which predict that these two low-energy conformers differ in energy by only ca. $2 \mathrm{~kJ} \mathrm{~mol}^{-1}$ and are separated by relatively high energy barriers $\left(>20 \mathrm{~kJ} \mathrm{~mol}^{-1}\right)$. The major factor that determines the structural preferences of monomeric MMAC is the conformation about the $\mathrm{C}-\mathrm{O}$ bond, as the trans conformers were predicted to have a significantly higher energy $\left(>30 \mathrm{~kJ} \mathrm{~mol}^{-1}\right)$ than the most stable $\mathrm{Ct}$ conformer.

In situ broadband excitation $(\lambda>235 \mathrm{~nm})$ of matrix-isolated MMAC resulted in the formation of nitrile ylide (P1) and ketene imine (P2) type products obtained by cleavage of the $\mathrm{C}-\mathrm{C}$ or $\mathrm{C}-\mathrm{N}$ bond, respectively. The latter process, unusual for aliphatic $2 \mathrm{H}$-azirines, had been previously observed for methyl 2-chloro3-methyl- $2 \mathrm{H}$-azirine-2-carboxylate (MCMAC) ${ }^{35}$ and rationalized by the simultaneous presence of two electron-withdrawing substituents (methoxycarbonyl group and chlorine atom) in that compound, which accelerate the intersystem crossing toward the triplet state and favor the $\mathrm{C}-\mathrm{N}$ bond cleavage over the usual $\mathrm{C}-\mathrm{C}$ bond breakage. Similar to what occurred in MCMAC, the $\mathrm{C}-\mathrm{N}$ cleavage was also found to be the preferred photoisomerization pathway for MMAC, thus demonstrating that the presence of the methoxycarbonyl group substituent at the azirine ring plays a crucial role in determining the unusual photochemical behavior observed for the two azirines. On the other hand, the observed secondary photoprocesses were found to be different in MCMAC and MMAC under the experimental conditions used. Indeed, contrary to MCMAC where both P1 and $\mathrm{P} 2$ type primary photoproducts were found to undergo secondary photoprocesses, in the case of MMAC, only P2 was observed to act as a reactant in secondary photoreactions (decarboxylation and decarbonylation), whereas no experimental 
evidence of further involvement of P1 in any subsequent photoprocesses could be obtained.

Acknowledgment. This work was funded by Fundação para a Ciência e a Tecnologia (FCT, Grant No. SFRH/BPD/17081/ 2004 and Projects POCI/QUI/59019/2004 and POCI/QUI/ 58937/2004), FEDER, and Agencia Nacional de Promoción Científica y Tecnológica (PICT 13080). A.G.Z. is a member of the Research Career of CONICET (National Research Council, Argentina). Calculations were partially done at the Academic Computer Center "Cyfronet", Krakow, Poland (Grant KBN/ SGI_ORIGIN_2000/UJ/044/1999), which is acknowledged for computing time.

Supporting Information Available: Table S1: optimized geometries [B3LYP/6-311++G(d,p)] for the conformers of MMAC; Table S2: definition of internal coordinates used in the normal coordinates analysis; Tables S3 and S4: full vibrational assignment for MMAC conformers; Tables S5S7: calculated vibrational data for photoproducts. This material is available free of charge via the Internet at http://pubs.acs.org.

\section{References and Notes}

(1) Pinho e Melo, T. M. V. D.; Rocha Gonsalves, A. M. d'A. Curr. Org. Synth. 2004, 1, 275.

(2) Pinho e Melo, T. M. V. D.; Lopes, C. S. J.; Rocha Gonsalves, A. M. d'A.; Storr, R. C. Synthesis 2002, 605. 543 .

(3) Padwa, A.; Smolanoff, J.; Tremper, A. J. Org. Chem. 1976, 41,

(4) Wendling, L. A.; Bergman, R. G. J. Org. Chem. 1976, 41, 831. (5) Padwa, A.; Smolanoff, J.; Tremper, A. J. Am. Chem. Soc. 1975, 97, 4682 .

(6) Padwa, A.; Dharan, M.; Smolanoff, J.; Wetmore, S. I. J. Am. Chem. Soc. 1973, 95, 1945.

(7) Padwa, A.; Dharan, M.; Smolanoff, J.; Wetmore, S. I. J. Am. Chem. Soc. 1973, 95, 1954.

(8) Alves, M. J.; Gilchrist, T. L.; Sousa, J. H. J. Chem. Soc., Perkin Trans. 1999, $1,1305$.

(9) Álvares, Y. S. P.; Alves, M. J.; Azoia, N. G.; Bickley, J. F.; Gilchrist, T. L. J. Chem. Soc., Perkin Trans. 2002, 1, 1911.

(10) Pinho e Melo, T. M. V. D.; Lopes, C. S. J.; Rocha Gonsalves, A. M. d'A.; Beja, A. M.; Paixão, J. A.; Silva, M. R.; da Veiga, L. A. J. Org. Chem. 2002, 67, 66.

(11) Palacios, F.; Aparicio, D.; Ochoa de Retana, A. M.; de los Santos,

J. M.; Gil, J. I.; Alonso, J. M. J. Org. Chem. 2002, 67, 7283.

(12) Bucher, C. B.; Heimgartner, H. Helv. Chim. Acta 1996, 79, 1903.

(13) Palacios, F.; Ochoa de Retana, A. M.; Martínez de Marigorta, E.;

de los Santos, J. M. Org. Prep. Proced. Int. 2002, 34, 219.

(14) Anderson, A. J.; Hassner, A. Synthesis 1975, 8, 483.

(15) Nair, V. In Heterocyclic Compounds; Hassner, A., Ed.; John Wiley and Sons: New York, 1983; Vol. 42, Part I, p 215.

(16) Palacios, F.; Retana, A. M. O.; Marigorta, E. M.; Santos, J. M.

Eur. J. Org. Chem. 2001, 13, 2401.

(17) Gilchrist, T. L. Aldrichim. Acta 2001, 34, 51.

(18) Kanehisa, N.; Yasuoka, N.; Kasai, N. J. Chem. Soc., Chem. Commun. 1980, 98.

(19) Piquet, V.; Baceiredo, A.; Gornitzka, H.; Dahan, F.; Bertrand, G. Chem.-Eur. J. 1997, 3, 1757.

(20) Barcus, R. L.; Wright, B. B.; Platz, M. S.; Scaiano, J. C. Tetrahedron Lett. 1983, 24, 3955.

(21) Barcus, R. L.; Hadel, L. M.; Johnston, L. J.; Platz, M. S.; Savino, T. G.; Scaiano, J. C. J. Am. Chem. Soc. 1986, 108, 3928.

(22) Frei, H.; Pimentel, G. C. Chemistry on Ground State and Excited Electronic Surfaces Induced by Selective Photoexcitation in Matrixes in
Chemistry and Physics of Matrix-Isolated Species; Andrews, L., Moskovits, M., Eds.; Elsevier Science Publishers B. V.: 1989; p. 139.

(23) Orton, E.; Collins, S. T.; Pimentel, G. C. J. Phys. Chem. 1986, 90 , 6139.

(24) Padwa, A.; Rasmussen, J. K.; Tremper, A. J. Am. Chem. Soc. 1976, 98, 2605.

(25) Albrecht, E.; Mattay, J.; Steenken, S. J. Am. Chem. Soc. 1997, 119, 11605

(26) Pfoertner, K. H.; Bernauer, K.; Kaufmann, F.; Lorch, E. Helv. Chim. Acta 1985, 68, 584.

(27) Pfoertner, K. H.; Montavon, F.; Bernauer, K. Helv. Chim. Acta 1985, 68,600 .

(28) Klessinger, M.; Bornemann, C. J. Phys. Org. Chem. 2002, 15, 514

(29) Bornemann, C.; Klessinger, M. Chem. Phys. 2000, 259, 263.

(30) Naito, I.; Ishida, A.; Takamuku, S.; Isomura, K.; Taniguchi, H. J. Chem. Soc., Perkin Trans. 1992, 2, 1985.

(31) Inui, H.; Murata, S. Chem. Phys. Lett. 2002, 359, 267.

(32) Inui, H.; Murata, S. Chem. Lett. 2001, 832.

(33) Inui, H.; Murata, S. Chem. Commun. 2001, 1036.

(34) Inui, H.; Murata, S. J. Am. Chem. Soc. 2005, 127, 2628.

(35) Gómez-Zavaglia, A.; Kaczor, A.; Cardoso, A. L.; Pinho e Melo,

T. M. V. D.; Fausto, R. J. Phys. Chem. A 2006, 110, 8081.

(36) Verstappen, M. M. H.; Ariaans, G. J. A.; Zwanenburg, B. J. Am. Chem. Soc. 1996, 118, 8491.

(37) Jacobsen, N.; Kolind-Andersen, H.; Christensen, J. Can. J. Chem. 1984, 62, 1940.

(38) Becke, A. D. Phys. Rev. A 1988, 38, 3098

(39) Lee, C. T.; Yang, W. T.; Parr, R. G. Phys. Rev. B 1988, 37, 785.

(40) Frisch, M.; Trucks, G.; Schlegel, H.; Scuseria, G.; Robb, M.; Cheeseman, J.; Zakrzewski, V.; Montgomery, J.; Stratmann, R.; Burant, K.; Dapprich, S.; Millam, J.; Daniels, A.; Kudin, K.; Strain, M.; Farkas, O.; Tomasi, J.; Barone, V.; Cossi, M.; Cammi, R.; Mennucci, B.; Pomelli, C.; Adamo, C.; Clifford, S.; Ochterski, J.; Petersson, G.; Ayala, P.; Cui, Q.; Morokuma, K.; Malick, D.; Rabuck, A.; Raghavachari, K.; Foresman, J.; Cioslowski, J.; Ortiz, J.; Baboul, A.; Stefanov, B.; Liu, G.; Liashenko, A.; Piskorz, P.; Komaromi, I.; Gomperts, R.; Martin, R.; Fox, D.; Keith, T.; Al-Laham, M.; Peng, C.; Nanayakkara, A.; Challacombe, M.; Gill, P.; Johnson, B.; Chen, W.; Wong, M.; Andres, J.; Gonzalez, C.; Head-Gordon, M.; Replogle, S.; Pople, S. Gaussian 98, revision A.9; Gaussian Inc.: Pittsburgh, PA, 1998.

(41) Frisch, M. J.; Trucks, G. W.; Schlegel, H. B.; Scuseria, G. E.; Robb M. A.; Cheeseman, J. R.; Montgomery, J. A., Jr.; Vreven, T.; Kudin, K. N.; Burant, J. C.; Millam, J. M.; Iyengar, S. S.; Tomasi, J.; Barone, V.; Mennucci, B.; Cossi, M.; Scalmani, G.; Rega, N.; Petersson, G. A.; Nakatsuji, H.; Hada, M.; Ehara, M.; Toyota, K.; Fukuda, R.; Hasegawa, J.; Ishida, M.; Nakajima, T.; Honda, Y.; Kitao, O.; Nakai, H.; Klene, M.; Li, X.; Knox, J. E.; Hratchian, H. P.; Cross, J. B.; Bakken, V.; Adamo, C.; Jaramillo, J.; Gomperts, R.; Stratmann, R. E.; Yazyev, O.; Austin, A. J.; Cammi, R.; Pomelli, C.; Ochterski, J. W.; Ayala, P. Y.; Morokuma, K.; Voth, G. A.; Salvador, P.; Dannenberg, J. J.; Zakrzewski, V. G.; Dapprich, S.; Daniels, A. D.; Strain, M. C.; Farkas, O.; Malick, D. K.; Rabuck, A. D.; Raghavachari, K.; Foresman, J. B.; Ortiz, J. V.; Cui, Q.; Baboul, A. G.; Clifford, S.; Cioslowski, J.; Stefanov, B. B.; Liu, G.; Liashenko, A.; Piskorz, P.; Komaromi, I.; Martin, R. L.; Fox, D. J.; Keith, T.; Al-Laham, M. A.; Peng, C. Y.; Nanayakkara, A.; Challacombe, M.; Gill, P. M. W.; Johnson, B.; Chen, W.; Wong, M. W.; Gonzalez, C.; Pople, J. A. Gaussian 03, revision C.02; Gaussian, Inc.: Wallingford, CT, 2004

(42) Császár, P.; Pulay, P. J. Mol. Struct. 1984, 114, 31

(43) Farkas, Ö.; Schlegel, H. B. J. Chem. Phys. 1999, 111, 10806.

(44) Peng, C.; Ayala, P. Y.; Schlegel, H. B.; Frisch, M. J. J. Comput. Chem. 1996, 17, 49.

(45) Peng, C.; Schlegel, H. B. Isr. J. Chem. 1993, 33, 449.

(46) Pulay, P.; Fogarasi, G.; Pang, F.; Boggs, J. E. J. Am. Chem. Soc. 1979, 101, 2550 .

(47) Martin, J. M. L.; Van Alsenoy, C. GAR2PED, University of Antwerp, Antwerpen, Belgium, 1995.

(48) Wiberg, K. B.; Laidig, K. E. J. Am. Chem. Soc. 1987, 109, 5935.

(49) Teixeira-Dias, J. J. C.; Fausto, R. J. Mol. Struct. 1986, 144, 199

(50) Lii, J.-H. J. Phys. Chem. A 2002, 106, 8667.

(51) Maçôas, E. M. S.; Khriachtchev, L.; Pettersson, M.; Fausto, R.; Räsänen, M. J. Phys. Chem. A 2005, 109, 3617.

(52) Barnes, A. J. Mol. Struct. 1984, 113, 161. 